\title{
TOWARDS INTENTIONAL NATURE OF INTERSUBJECTIVITY
}

\author{
ANNA KHAKHALOVA \\ Assistant professor of the East-European Institute of Psychoanalysis, 197198 St. Petersburg, Russia. \\ E-mail: khakhalova@mail.ru
}

The problem addressed in this paper is the genesis of the empathetic, intersubjective intentionality which underlies secondperson interactions. This theme is one of the most intriguing in contemporary philosophy and interdisciplinary research. The article seeks to elucidate the foundations of the phenomenon of the other which we always already have in our daily embodied practices. First, we present a critical analysis of some aspects of the theory of intersubjectivity, such as analogical inference, anonymity of intersubjective being, inaccessibility of immediate experience of the Other. Then, based on such topics, as corporeity, the enactive nature of subjectivity, historical and social aspects of subjectivity, we elaborate the concept of empathy as lying at the very foundation of any encounter with the Other. As a result, we demonstrate the closeness of Husserlian idea of non-objectifying intentionality to the empathetic approach in contemporary philosophy. As precursors of the latter we mention M. Buber, L. Wittgenstein, M. Sheler, who advocate the dialogical (second-person) structure of consciousness and its em/ sympathetic nature. We also present an interpretation of empathy as an exclusive and unique form of intentional relation (E. Thompson) which permits to experience the Other in a direct, immediate way from second-person percpective (Sh. Gallagher). The analysis of empathy is also promising for contemporary interdisciplinary studies of affective consciousness, which are also mentioned. The article stresses the necessity of further studying «being-with» in both phenomenological and interdisciplinary dimensions to the extent that intersubjectivity constitutes the sense of the self on both transcendental and experiential levels.

Key words: affectivity, corporeity, tradition, anonymity, sociality, embodied practices, intentionality.

\section{К ИНТЕНЦИОНАЛЬНОЙ ПРИРОДЕ ИНТЕРСУБЪЕКТИВНОСТИ}

\author{
АННА ХАХАЛОВА \\ Старший преподаватель Восточно-Европейского института психоанализа, 197198 Санкт-Петербург, Россия. \\ E-mail: khakhalova@mail.ru
}

Данная статья обращается к проблеме генезиса эмпатической, интерсубъективной интенциональности, которая лежит в основании отношений с перспективы второго лица. Эта тема - одна из самых интригующих в современнной философии и в медисциплинарнх исследований. Автор стремится прояснить основания феномена другого, составляющего неотъемлемую часть нашего повседневного опыта. В первой части статьи представлен критический анализ некоторых аспектов теории интерсубъективности, таких как аналогический перенос, анонимности интерсубъективного бытия, недоступность непосредственого переживания другого. Затем, ориентируясь на такие темы, как телесность, деятельностная природа субъективности, историческое и социальное измерение субъективности, автор указывает на разработку понятия эмпатии как необходимого условия встречи с другим. В качестве результата статья демонстрирует близость гуссерлевской идеи не-объективирующей интенционалньости эмпатическому подходу в современной философии. В качестве предшественников последнего можно указать М. Бубера, Л. Витгенштейна, М. Шелера, которые открывают диалогическую структуру сознания и ее эм/симпатическую природу. Автор также представляет интерпретацию эмпатии как исключительной формы интенционального отношения (Томпсон), которая позволяет переживать опыт другого в его непосредственной данности с перспективы второго лица (Ш. Галлагер). Анализ эмпатии, кроме того, может быть многообещающим для современных исследований аффективного сознания, которые также упоминаются. Статья подчеркивает необходимость дальнейшего изучения «бытия-с» в феноменологической традиции и в междисциплинарном пространстве в той степени, в какой интерсубъективность конституирует чувство самости как на оптном, так и на трансцендентальном уровнях.

Ключевыеслова: аффективность, телесность, традиция, анонимность, социальность, телесныепрактики, интенциональность.

(C) Anna Khakhalova 
The question of our co-existence, our being with others is the most intriguing theme in phenomenological tradition. How do we know each other? What lies in the foundation of our necessity to recognize and to be recognized by another person in our habitual life? Such questions were suggested by Husserl in "Cartesian Meditations» and were shared by many other philosophical traditions (philosophy of dialogue, analytical philosophy, psychoanalysis et cetera). Numerous conceptions of intersubjectivity, presented in contemporary philosophical and scientific literature, raise same questions in order to elucidate the foundations and conditions of such inter-relational reality.

There is no secret that most of the time we are interacting with others - in our daily life, literature and movies, in most personal situations, in exceptional and exclusive times. From the beginning of our life - in unique co-attuned experience with mother - to the last time we feel and know "what it is like to be with another person". In fanciful way the question about the nature of the Other inverts into the question about oneself, about «I». Who am I, whom the Other addresses? Repeating Aristotle's definition, we argue that human being is dzoon politicon, which means that we exist in a form of being-with (Mit-Sein). As R. D. Stolorow and J. Atwood note, the truth of our, in principle, intersubjective constitution long time was unconsciously repressed due to attraction of the Myth of isolated mind. ${ }^{1}$ This isolation inevitably spreads to other contexts of being, in which the subject exists and acts, in the form of concepts and prejudices which guide our comprehension and constitutively participate in our cognition of reality. Thus, the idea of the subject in classical tradition proves to be quite limited by the monadic conception of development - some kind of ding-an-sich that does not point to any alternative ways of being beyond itself.

The significant achievement in phenomenological and existential-oriented philosophy and psychology is acknowledgement of ontogenetic primacy of coexistence with others and postulating it as a genuine form or aspect of subjectivity itself, inseparable from it.

\section{THE ENACTIVE NATURE OF SUBJECTIVITY}

Husserl and Merleau-Ponty affirm that alterity constitutes our subjectivity and that this constituting role of alterity is revealed in the phenomenon of embodiment. Nevertheless, we need to demarcate the positions of the two authors. For Husserl, the starting point consists in the experience of double sensation (Doppelrealität): on the one hand, my body presents itself as the intrinsic sphere of my voluntary actions (Innenkeit), on the other - as an object of my perception (Aussenleiblichkeit), as it is in the case of alternatively touching and touched hand. ${ }^{2}$ The phenomenon of double sensation is criticized by many philosophers as too artificial; in addition, both Sartre and Merleau-Ponty show that it does not correspond to the original experience of the body. Sartre denies any form of alterity in experiencing one's own body because it is only from the Other proper, the Other as such that I can get the very idea of alterity (Lévinas also insists on the absolute transcendence and foreignness of the Other who gives me initially the very meaning of alterity). Merleau-Ponty takes a different view. According to him, corporeity is already a sign of alterity in itself: it is my body which the Other sees first, it is the body of the Other that I see first. As such, the embodiment of our experience points to our primary social, intersubjective, corporeal mode of being which exist as primary perceptual unity before the subject-object division. So, in order to execute the identification by means of double sensation one already needs to have a form of self-acquaintance with one's own body, to experience a more primordial level of self-consciousness. This «original sphere of existence» (Henry) shapes

\footnotetext{
The myth is well-known under the name of «classical or Cartesian metaphysics» in which the subject is isolated from his own body while aspiring to some independent inner free existence and development of consciousness (Stolorow \& Atwood, 1987).

2 T. Carman posits that Husserl even in «Ideas-II» still considers the body as an object, or quasi-object, which has an intentional dimension only in so far as it is a pole, locus, topos of localized sensation. According to Husserl in the identification of the body as mine, the touching hand performs a subjective activity when it grasps a passive object, namely the touched hand (Carman, 1999).
} 
the transcendental constitution of subjectivity from the immanence. I exist in bodily oriented world as a comprehensive agent and as one who feels kinetic-affective dynamics. It is the dynamics by means of which I am acting in the world, i. e. I interpret it as mine. Following Husserl, phenomenologists call this original sphere of existence "Ich kann» - a system of free possibilities for movement, action. But unlike Husserl who grounds this system in the sphere of ownness, Sheets-Jonstone tends to reach the asubjective or pre-personal sphere of primary animation, from which any sense of the self can be traced. The ontogenetic primacy of the sphere of animation over other more sophisticated forms of selfhood, is characterized by habituality and familiarity - our initial form of self-understanding. This idea can be expressed in the following: every «thought and sensation as such occur only against a background of perceptual activity that we always already understand in bodily terms, by engaging in it» (Carman, 1999, 206). As Merleau-Ponty points:

I have the world as incomplete individual, through the agency of my body as potentiality of this world, and I have the positing of objects through that of my body, or conversely the positing of my body through that of objects, not in any kind of logical implication $<\ldots>$ but in a real implication, and because my body is a movement towards the world, and the world my body's point of support (Merleau-Ponty, 1962, 408).

As such, «seeds of alterity», due to which we anticipate the Other and are not fully transparent to ourselves, are founded in our ordinary embodied practices. As such, my body is firsttranscendence in immanence. In defending the primacy of the sphere of animation above the sphere of ownness, we can address psychological experiments, which show that disruption of this ordinary tacit self-awareness makes us lack the immunity of wrong identification. ${ }^{3}$

Emphasizing active, dynamic nature of subjectivity, which is realized in the experiential prereflective self-awareness, Sheets-Jonstone interprets this affective-kinetic dynamics, this coupling of «movement and affectivity as the primordial ground of animation» (Sheets-Jonstone, 2006, 382). As pre-reflexive process self-affection discloses passive constitution of every action and thought. It is the passivity through which the Other appears to me. As we can see, emphasizing action permits us to embed the very core of intersubjectivity in corporeity, thereby eluding a metaphysical and overintellectualist conception of the body and isolated mind. Self-affection presents initial bounding between corporeity and worldness. Starting from this opening, we achieve the understanding of others as a tissue of the bounding. In other words, the Other is not foreign for me, but already exists along my own existing as a co-constituent of my subjective reality. Obviously, the reality tends to be treated as inter-reality or inter-subjective reality. In order to elaborate the essential features of such reality, we can elucidate our conception of intersubjectivity and the idea of unique form of intentionality expressed by it. Let us to reconsider several aspect of the problem, such as intropathy (Husserl), theory of mind (Premack, Woodruff and many others) and the absolute foreignness of the Other (Sartre, Levinas).

Husserlian theory of Fremderfarung shares its main presuppositions with Benno Erdmann's theory of inference by analogy and Theodor Lipps' theory of empathy. ${ }^{4}$ Every theory of analogy and inference bears a label of reductionism: the sense of the Other is derived from mere observable physical events, or behavior, which are designed to represent the Other's mental phenomena behind them. According

The rubber hand, where you have the sense of ownership, whereas there is no appropriate proprioceptive information. A syndrome of alien hand and a few others demonstrate inverse occasion, where one has prorioception, but does not feel a part of body (a hand) as his own, i.d. there is no appropriate phenomenological sense of possible movements for this part. Erdmann insists on the inferential character of the other's being mediated by our bodily behavior. I carried out this knowledge about the Other analogically. Lipps also advocates the derived sense of the Other, presenting him as the product of a mental activity, namely, of a «duplication of myself» (die Vervielfältigung meiner selbst). This duplication is motivated by certain sense-perceptions of the Other's body and is called «empathy». S. Overgaard argues that the first articulation of the analogical argument can be found in An Examination of Sir William Hamilton's Philosophy by John Stuart Mill. 
to this view, to be in joy means to display a certain type of behavior. All these theories are based upon Cartesian body/mind dualism and on the presupposition about principal inaccessibility of the Other, both of which constrain contemporary studies of mind. ${ }^{5}$ Husserl also falls prey to the idea of the inaccessibility and unobservable character of alter ego. Since there are only some kinesthetic syntheses, bodily manifestations exterior to me, in immediacy of my look, I can infer about foreign subjectivity only by means of analogical apperception and pairing (Paarung).

Analogical apperception falls under the general heading of «appresentation». When the front of a physical object is evidentially present to me in perception, its back is co-presented, co-intended or apperceived by me. I am motivated by the present aspect of the object to constitute the object as having other aspects not now present but included within the totality of the object as intended $\langle\ldots>$ In the case of the other, it is his body that is evidentially present and his consciousness or subjectivity that is appresented... (Dillon, 1998, 116).

The «apperceptive transfer from my animate organism» is carried out in "a manner that excludes an actually direct, and hence primordial, showing of the predicates belonging to an animate organism specifically, a showing of them in perception proper» (Welton, 1999, 147). Husserl argues that "[e]go and alter ego are always and necessarily given in an original "pairing"» (Welton, 1999, 148). Pairing consists in a passive associative constitution of the sense of the other. An association is accomplished (which Husserl places under the problematic heading of "passive synthesis») between my body and other's one which constitutes them as a pair, as a phenomenologically revealed «unity of similarity». Dillon compares pairing with the transfer of corporeal schema in Merleau-Ponty: namely, I perceive the conduct of the other and co-experience the same somehow from a distance by transferring my intentions to alter ego and her to mine, that is, by execution of mutual alienation. As such,

Husserl's account of pairing is placed within the context of isolated immanence, the sphere of ownness that he regards as primordial, whereas Merleau-Ponty places the transfer of corporeal schema within a context of «syncretic sociability», a context defined as prior to any distinction of perspectives or differentiation between what is mine and what is other (Dillon, 1998, 118).

Nevertheless, in both of them we can observe derived sense of the other, which means that the other is fashioned as I in potentiality, «as if I was there». Thus, we can conclude that pairing consists in initial «mirroring» of my ego, or equally in imitation of the other. ${ }^{6}$ While Husserl adopts the presupposition of «nascent solipsism», Merleau-Ponty, on the contrary, describes infantile conscious life in terms of syncretism or indiscernibility of perspectives. From latter perspective, the problem is not «how does the infant begin to recognize other as other consciousness?» but rather «how does the infant learn to differentiate himself and others as separate beings within a sphere of experience that lacks this differentiation?» (Dillon,1998, 121). In order to demonstrate the phenomenon of syncretic sociability, Merleau-Ponty refers to infant's experience:

We can find similar argumentation in the so called theory of mind (TOM), which exists either in the form of the theory theory (TT) and the simulation theory (ST). According to TT, children understand the Other only by employing a theoretical stance, which includes postulating the existence of mental states in others, predicting and explaining them. Simulation theory argues that «that one does not theorize about the other person but uses one's own mental experience as an internal model for the other mind $\langle\ldots\rangle$ To understand the other person, I simulate the thoughts or feelings that I would experience if I were in the situation of the other. I emulate what must be going through the other person's mind; or I create in my own mind pretend beliefs, desires or strategies that I use to understand the other's behavior» (Gallagher, 2001, 84-85). There is a variety of TOM versions in contemporary philosophy which may combine some elements of the two theories mentioned.

6 The famous findings of Meltzoff and Moore in neonate's facial imitation confirm this idea (Meltzoff \& Moore, 1977). 
...child lives in a world which he unhesitatingly believes accessible to all around him. He has no awareness of himself or of others as private subjectivities, nor does he suspect that all of us, himself included, are limited to one certain point of view of the world. That is why he subjects neither his thoughts, in which he believes as they present themselves, without attempting to link them to each other, nor our words, to any sort of criticism. He has no knowledge of points of view. For him men are empty heads turned towards one single, self-evident world where everything takes place, even dreams, which are, he thinks, in his room, and even thinking, since it is not distinct from words (Merleau-Ponty, 1962, 318).

The corporeal schema manifests itself in «an overlapping of the infant's experience of his body and his experience of other bodies: he sees others doing what he sees himself doing, and vice versa. The notion of corporeal schema renders mimetic behavior conceivable and provides a theoretical foundation for the phenomena of transitivity» (Dillon, 1998, 122). Eliminating the difference between immanence (Leib) and transcendence (Körper), Merleau-Ponty grounds intersubjectivity in the original anonymity of bodily practices.

From this perspective the sphere of animation can be interpreted as an initially social dimension. For following explications one could consider our daily embodied practices. As being-in-the world we are embedded in the ready-to-hand sphere of artifacts, tools or pieces of equipment, which we share with others. As Husserl notices, the identity of the thing emerges from an intersubjective exchange of one and the same thing. As Heidegger added, the sense of the thing consists in its «inorder-to", in its ecological or phenomenological meaning. The same is convenient for language. Such existentials as Befindlichkeit and Geworfenheit point to the most intimate and individual features of my own being, which are at the same time publicly opened and accessible for others who engage with me.

The Analysis of corporeal schema leads us up to the conclusion of constitutive role of others in the process of meaning-making of things, words, events and of the world in general. Others as co-constituents of the reality and co-performers of my intentional acts are marked in phenomenology as tradition. «I learn what counts as normal from others, and indeed, initially, and for the most part, from those closest to me, hence from those I grow up with, those who teach me, and those belonging to the most intimate sphere of my life» (Husserl, $1973 \mathrm{~b}, 428-429$ ). I thereby participate in a communal tradition, which through a chain of generations stretches back into a dim past. I have always been a member of a community. I am born into it; I grow up in it. The historical is a living past handed down to me; it is a living force in me» (Zahavi, 2005, 166). Passive synthesis means that «any such ego cogito necessarily presupposes that the object affecting the Ego-pole and inciting it to act is previously already constituted in the sphere of passive intentionality to which the activity of Ego has not yet spread» (Borisov, 1999). In other words, there is something in my perception that is not produced by me, but is inherited from others in the form of tradition. «This permits to consider passive synthesis as a form in which the process of intersubjective constitution of my Ego is manifested for me and, therefore, as a form of the presence of alter ego in my own consciousness...» (Borisov, 1999).

Moreover, tradition affects the way in which I see the other, the way of my comprehensive-interpretative existence. Namely, having accumulated experience, with time I acquire a second nature, some habitual history of my self, my own style of narrating, which I impose on the other in the situation of experience. The other in his turn also makes me correspond to his style of narration. «Ego ... affects another Ego and inversely, it assimilates the acts of another Ego thereby becoming a bearer of foreign spiritual functions» (Husserl, 1959, 506). Assimilating the habitual style of the other, I transform, enrich and complete my own historical being. 
We remember that, according to the phenomenological theory of identity, unlike ordinary things I (as ego ipse) need a different kind of verifying my identity. In the former case, I realize that it is the same $\mathrm{X}$ as it was a second ago. This $\mathrm{X}$ maintained within the limits of its own horizon of meaning is invariable. It is identical to a large degree due to my being able to communicate its meaning to the other as well as due to the possibility of the event of comprehension by myself and by the other of this $\mathrm{X}$, of some consent on this X. But unlike things, in accordance with my nature - in the Heideggerian sense of physis - I dwell in continuous change since I am somebody who counts the time. I cannot say that my present self is identical to myself a second ago since I have changed, I have reflected on this moment of time, I have interpreted and understood my being as it was a second ago and hence I have already accomplished an existential difference (between my past and present selves). However, I need the other in order to state that my past self is identical to myself at present and in the future; identity meaning here my past and present selves mutually belonging to each other. Identity is for me a criterion for differentiating existential differences (past and present) into mine and somebody else's. The other will be for me somebody who never coincides with me at present as my past self does with my present self. The experience of correlating two moments of time me in the past and me at present, permits me to conclude on such an entity as my self, on my being "unity in difference». According to this interpretation, identity means something that first emerges from intersubjective interaction. But intersubjective field is not reducible to identity verification since it is not just one thing among others, it is nothing of existent things at all. Intersubjectivity is before the identifying experience as primary energetic co-constitution of identity as such, in particular of my identity as my self and of the other's identity as the other's self. If pregivenness is understood in this specific way, then intersubjectivity can be said to pre-cede (be pre-given with regard to) my Ego in the ontogenetic order, as some primary proto-Ego (Ur-Ich), whose «main essential characteristic is its primacy with regard to any identical (and accordingly, identifiable) intentional formations, in particular with regard to ego and alter ego» (Borisov, 1999). But when I find myself in an assimilated historical tradition, I invest this tradition with sense as trans-egological being exceeding the limits of my own history. In this movement I am alienated from myself, from the sphere of my own, in favor of tradition as such. I endow it with meaningfulness for all the possible others considering them as bearers of this tradition. Only when the tradition of my Ego and of the Other acquires unity, such a historical event as comprehension becomes possible. In uniting the two moments of appropriating historical tradition, narrative Ego acquires the sense of an entity, which in dialectics of self-alienation seeks to come where Id used to be, to use Freud's expressionю «I» seeks to come to the place where the sphere of my own develops into historical being, trying to dissolve its Faktizität, its hermeneutical situation in historical tradition as such. The boundary between activity and passivity is not stable, it is susceptible to shifting. I always reactivate passive genesis, extending the sphere of my own being. The figure of the Other is presented here as immanent to my own being. In turn, such «infantile» drive as «drive to Death", to nihilation of oneself, to disappearing in Nothingness cannot be completely accomplished, except some forms of disorders of the self. On experiential level there is always tacit self-awareness, which holds me in uniqueness and exclusivity. Seemingly, there is no experiential prove of anonymous existence due to incessant sensing of the self.

\section{THE PRESENCE OF THE OTHER}

Models of intersubjectivity discussed above share common ontological assumption about derived sense of the Other, his indirect way of presence in my experience. In defence of this pressuposition the authors postulate the indiscernibility and anonymity of co-existence, in which I assimilate others as my own past and pre-given experience, or as a space of alternativity of look, perception, experience 
in whole. Is there a possibility to break forth to the real alive Other, who is grasped not as an animate organism, physical body, a copy of my own, but as the Other, to whom I address, from whom I expect recognition, understanding, emotional response, with whom I co-exist, co-change and co-create the world? Of course, there are already tendencies towards more intimate and direct character of experience of the Other in these theories. As E. Borisov mentions, "[a]pparently, the notion of proto-I can be interpreted as holistic meaningful space of intersubjective relations... the space of co-constitution of the ego and the alter ego as equally initial, "irreducible" to each other constitutive centers» (Borisov, 1999). Appealing to genetic phenomenology, Nam-In Lee reveals two kinds of intentionalities in Husserl's later manuscripts. While the static phenomenology studies mostly objectifying intentionalities («intentionality that posits a thing as my body and myself as a person, the intentionality that posits the resemblance between the body of the other person and my body» (Lee, 2006, 150)) the genetic one discern

various kinds of non-objectifying intentionalities such as willing, feeling, drive etc. This is due to the fact that the empathetic presentiation could be motivated by these non-objectifying intentionalities... There are many such willings, for example, the will to learn from the other, the will to inform the other, the will to love the other, etc. All these willings that are aimed at contacting the other persons can be called social willings (Lee, 2006, 150),

or social drives and instincts. To will to do something with or towards the Other presupposes tacit awareness of what it is like to be with others, the sense of others. That is the corner stone of all projects of intersubjectivity which criticize the ontological assumption of the inaccessibility of the Other. For example, the philosophy of dialogue, M. Sheller, L. Wittgenstien and contemporary interdisciplinary researchers (Sh. Gallegher, C. Trevarthen, R. Stolorow, E. Tronick and many others) - all of them insist on the immediacy of the Other in relational situation, on his openness and responsiveness towards me. It is this idea of immanence in transcendence, defined by Heidegger and Merleau-Ponty as being toward the world and toward the Other, which functions on the bodily and pre-reflexive level. ${ }^{7}$ Before I construct a theoretical stance towards the Other, constitute the sense of the Other as alter ego, alter lived-body or as a tradition, I have already the sense of the Other, the meaning of Thou from our second-person interactions. These authors insist on the possibility of presence (Gegenwärtigung) of the Other in my experience. Moreover, the sense of the self is an achievement of primary interactions with others. Such feelings as fear, anger, shame are given to me not as a data hidden in one's physical body and requiring inference. On the contrary, I can immediately see that a person is afraid, feels anger, joy, grief etc., and I don't need to inferentially conclude on their feelings, since they are manifested in conduct, bodily gestures or bodily-affective dynamics. ${ }^{8}$ The capacity to co-experience with the Other the same feeling explores our initial attitude of sympathythat is openness and situation of "inter-esse" towards each other. This stance of sympathy is activated in a form of intersubjective intentionality from the beginning of the life and is ongoing all the rest of our life on a pre-reflective, non-conceptual level. The intentionality includes emotional, sensory-motor and perceptual aspects, and has second-person character, and nonconceptual. In his book "How the body shapes the Mind», Sh. Gallagher addresses neuroscientific research of neonate's abilities in differentiating experiential world. Namely, they make delineation of all the sphere of visual perception, dividing all objects in two classes: other persons and the rest of unanimated objects. Our vision is already attuned to the shapes that resemble our own. These findings can explain the fact of

\footnotetext{
Nevertheless, Heidegger insist on primary form of being for Dasein, that is being-in-the-world, which is ontological ground for the self to be a Thou, to become a careful and responsible for the other, whereas for adepts of immediate experience of the other there is ontological parity of being-in-the-World and being-with-others. See U. Neisser's conception of the five-leveled sense of the self, where there are established from the beginning of life two equally foundational form of the self - ecological (being-in-the-world) and intepresonal (being-with-others).

8 For more broad account of such phenomenon (Zahavi, 2005; Overgaard, 2010).
} 
neonate's imitation at minutes after birth. Researchers also hold that «second-person interactions» are «not only primary in a developmental sense, but constitute the primary way we continue to understand others in the rest of our life» (Gallagher, 2001, 86). The guiding role here belongs to affect, which is defined by R. D. Stolorow and J. Atwood as an organizing factor of experience (Stolorow \& Atwood, 1987). E. Thompson in his turn in order to describe this kind of interaction has recourse to the term «empathy» which is presented by him as a unique and irreducible kind of intentionality being «the precondition (the condition of possibility) for the science of consciousness» and «is an evolved, biological capacity of the human species, and probably of other mammalian species, such as the apes» (Thompson, 2001, 2).

In postulating a special kind of intentionality for describing second-person interactions we acknowledge the unique and exclusive form of presence under the keen of the Other, who challenges and excites my world, demands intentional modification of my optics. We already know that in the center of this modification is affective-emotional mutual regulation between each other. In other words, as being-with-others I always somehow feel myself with them, by attuning to their feeling, states of mind, moods and so on. This is the ontic level of what Heidegger discovers under the name of Befindlichkeit. We have careful feelings to each other such as concerns and worries, happiness and sorrows among which disinterest, a kind of a-pathos, is also one of the modification of Care.

According to this line of thought, many philosophers and scientists elaborate affective experience as the primary form of self (N. Depraz, K. Wider, A. Damasio, J. Panksepp, C. Trevarthen etc.). It means that we already have some knowledge about ourselves and already understand our self before explicit forms of self-consciousness come into play. It also means that our implicit knowledge of being-with-others has bodily-affective nature. In addition, Evan Thompson notices the ubiquitous character of affect:

\begin{abstract}
Affect has numerous dimensions that bind together virtually every aspect of the organism the psychosomatic network of the nervous system, immune system, and endocrine system; physiological changes in the autonomic nervous system, the limbic system, and the superior cortex; facial-motor changes and global differential motor readiness for approach or withdrawal; subjective experience along a pleasure-displeasure valence axis; social signalling and coupling; and conscious evaluation and assessment (Thompson, 2001, 3).
\end{abstract}

In psychoanalytic tradition affective responsiveness starts to play crucial role in post-Freudian tradition in connection with the theme of personal neurotic history. Such phenomenologically oriented psychoanalysts as D. Stern, E. Tronick turn to Dynamic Systems Theory in order to elaborate more adequate theoretical conception of the subject. According to it, all relationships have a number of invariants: temporal, enactive, affective and so on, which both the infant and the mother require as far as they are reaching affective attunement. Tronick et al. name this state of relationship «dyadic state of consciousness», assenting systematic features of this state, such as capability of re-actualizing process, or self-organizing principle, teleological principle to become more thick and stable, to gain dyadic thickness and the others. In Heideggerian and existential manner Tronick emphasizes «the moments of meeting» of this co-creative process of dyad. As «intimate level» in Bugental these moments shed "something more than interpretation» in therapeutic interactions that is, such level of communication which goes beyond reflexive articulation, but impacts crucial changes in dyad's history, re-organizing and deconstructing previous disruptive tendencies, patterns and habits (Stern et al., 1998). These situations of authentic encounter, when «I» sees «Thou» not lasts long and as «kairos» demand from the subject his staying in «openness and decisiveness» towards this situation and towards the Other in it. These findings can be assimilated by phenomenological thought and impact the theory of subjectivity. 


\section{CONCLUSION}

We presented the genesis of intersubjective intentionality in phenomenological tradition, where we mentioned a variety of approaches and conceptions of the Other. Here we presented some aspects of Husserlian, Merleau-Ponty's and Heideggerian philosophies and also some contemporary approaches, which reject the ontological assumption of principal inaccessibility of the Other's experience. Instead of it philosophy of dialogue, phenomenology of sympathy, empathetic approaches to mind maintain the idea of directly experiencing the Other, and it is present in the etc. This idea eliminates the inherited dualistic metaphysical problems due to a non-reductive, non-intellectualistic and more adequate conception of what it is like for somebody to interact with the Other, to feel one's joy and sorrow.

We pointed out that second-person interactions have exclusive and unique form of intentionality empathetic or intersubjective - which reveals the very «presentation», presence of the Other as «Thou». This kind of intentionality includes bodily-affective co-attunement of subjects, demonstrating their communication as a dyadic process. Moreover, the affective-emotional point of view allows us to avoid positing the primary anonymity and indiscernibility of myself and the Other, owing to phenomenal qualities alternating both first-person givenness and second-person perspective. My feeling your pain is not tantamount to physically sensing this pain. I need not theorize about what is happening to you and how you are feeling now, because I can see it immediately. It also avoids the idea of alienation and radical otherness of the Other.

On the basis of the concrete encounters with «Thou», we can conclude on ontogenetic primacy of intersubjectivity and on transcendental structures that underlie this experiential level in the form of Life-World of the subject. The analysis of passive genesis manifests the inherence of others in my own existing as society, as cultural world and as tradition, therefore, enriching our insight into the intersubjective nature of the ego.

\section{REFERENCES}

Borisov, E. V. (1999). Problemy intersubectivnosti v fenomenologii [Problems of Intersubjectivity in Phenomenology]. In V. V. Anashvili, A. L. Pogorel'skii (Eds.), Logos 1991-2005. Izbrannoe v 2 T. T. 2. [Logos 1991-2005. Selected Articles in 2 Volumes. Volume 2]. Moscow: Territory of the Future Publ.

Carman, T. (1999). The Body in Husserl and Merlo-Ponty. Rhilosophical Topics, 27 (2), 205-226.

Dillon, M. C. (1998). Merleau-Ponty’s Ontology. USA: Indiana University Press.

Gallagher, S. (2001). The Practice of Mind: Theory, Simulation, or Interaction? Journal of Consciousness Studies, 8 (5-7), 83-108.

Gallagher, S. (2005). How the Body Shapes the Mind. Oxford: Oxford University Press.

Husserl, E. (1959). Erste Philosophie. Zweiter Teil. (Hua VIII). Den Haag: Martinus Nijhoff.

Husserl, E. (1973 a). Zur Phänomenologie der Intersubjektivität. Zweiter Teil. (Hua XIV). Den Haag: Martinus Nijhoff. 
Husserl, E. (1973 b). Zur Phänomenologie der Intersubjektivität. Dritter Teil. (Hua XV). Den Haag: Martinus Nijhoff.

Lee, Nam-In. (2006). Problems of Intersubjectivity in Husserl and Buber. Husserl Studies, (22), 137-160.

Meltzoff , A. N., \& Moore, M. K. (1997). Explaining Facial Imitation: A Theoretical Model. Early Development and Parenting, (6), 179-192.

Merleau-Ponty, M. (1962). Phenomenology of Perception. London, NewYork: Routledge.

Overgaard, S. (2010). The Problem of Other Minds. In D. Schmicking, \& Sh. Gallagher (Eds.), Handbook of Phenomenology and Cognitive Science (255-268). USA: Springer.

Sheets-Jonstone, M. (2006). Essential Clarifications of "Self-Affection" and Husserl's "Sphere of Ownness": First Steps Toward a Pure Phenomenology of (Human) Nature. Continental Philosophy Review, 39 (4), 361-391.

Stern, D. N., Sander, L. W., Nahum, J. P., Harrison, A. M., Lyons-Ruth, K., Morgan, A. C., ...Tronick, E. Z. (1998). Non-Interpretative Mechanisms of Psychoanalytic Therapy. The "Something More" than Interpretation. The Process of Change Study Group. International Journal of Psycho-Analysis, 79 (5), 903-921.

Stolorow, R. D., \& Atwood, G. E. (1987). Clinic Psychoanalysis. An Intersubjective Approach. London: The Analytic Press.

Thompson, E. (2001). Empathy and Consciousness. Journal of Consciousness Studies, 8 (5-7), 1-32.

Zahavi, D. (2005). Subjectivity and Selfhood. Investigating the First-Person Perspective. Cambridge: MIT Press.

Welton, D. (Ed.). (1999). The Essential Husserl. Basic Writings in Transcendental Phenomenology. USA: Indiana University Press. 